\title{
One-Step Procedure for Direct Purification of Pediocin-Like Bacteriocins and Cationic Antimicrobial Peptides from Complex Culture Medium on an Analytical, Semipreparative, and Preparative Scale. A New Type of Liquid Chromatography-Colloidal High-Performance Liquid Chromatography (CHPLC)
}

\author{
Ilia Brondz \\ Norwegian Drug Control and Drug Discovery Institute (NDCDDI), Ski, Norway \\ Email: ilia.brondz@gmail.com
}

How to cite this paper: Brondz, I. (2018) One-Step Procedure for Direct Purification of Pediocin-Like Bacteriocins and Cationic Antimicrobial Peptides from Complex Culture Medium on an Analytical, Semipreparative, and Preparative Scale. A New Type of Liquid Chromatography-Colloidal High-Performance Liquid Chromatography (CHPLC). International Journal of Analytical Mass Spectrometry and Chromatography, 6, 41-49.

https://doi.org/10.4236/ijamsc.2018.63004

Received: July 3, 2018

Accepted: September 3, 2018

Published: September 6, 2018

Copyright $\odot 2018$ by author and Scientific Research Publishing Inc. This work is licensed under the Creative Commons Attribution-NonCommercial International License (CC BY-NC 4.0). http://creativecommons.org/licenses/by-nc/4.0/ (c) (i) (8) Open Access

\begin{abstract}
A simple time- and labor-saving one-step procedure suitable for analytical-, semipreparative-, and preparative-scale preparation of bacteriocins and other cationic antibacterial peptides (for example as lysozyme) has been developed. Suspensions of bacterial cells, other colloidal- and fast-particle materials, and dissolved anionic molecules passed through the column; however, cationic bacteriocins were separated by chromatography. The purity of the target substance at more than $97 \%$ was achieved by the judgment of spectral, chromatographic, and antimicrobial activity. A many-fold concentration increase was achieved for bacteriocins, lysozyme, and bacitracin (a commercial antibiotic) in comparison with the starting solutions (see the text below). In the experiments, homemade cation-exchange columns have been used. The columns have been prepared by the grafting of glass fibers with a diameter of 0.2 $\mu \mathrm{m}$. In this paper, applications of a new type of liquid chromatography-colloidal high-performance liquid chromatography (CHPLC)-were demonstrated.
\end{abstract}

\section{Keywords}

Liquid Chromatography, Bacterial Cells, Bacteriocins, Antibacterial Peptides, Lysozyme, Bacitracin, Cation-Exchange Columns, Grafting, Glass Fibers, 
New Type of Liquid Chromatography, Colloidal High-Performance Liquid Chromatography

\section{Introduction}

The discovery of colicin V, a bacteriocin, by André Gratia (1893-1950) in 1924-25 has been mentioned in [1] [2] [3]. Sir Alexander Fleming, in 1923, had discovered the bacteriolytic property of a cationic animal enzyme, lysozyme. The discovery of the first fungus antibiotic substance-penicillin - by Fleming put a hold on the development of bacteriocins; the second factor in the delay in development of bacteriocins was World War II. Many generations of penicillin have been developed since and up today [1], together with many generations of tetracyclines [1]. However, growing microbial resistance and multi-resistance to antibiotics developed today has turned attention to several other classes of antibacterial substances-antibiotics from plants [4]-[13] and other sources. Some of the well-known antibiotics have unwanted side effects [14]. The antibiotic-resistant and multiple antibiotic-resistant (especially Methicillin-Resistant Staphylococcus aureus (MRSA)) species are the result of mass migration and insufficient hygiene and sanitation in the developing countries from which the mass migrations take place [1] [15]. The same phenomenon of spreading unknown new diseases in the regions to the native population occurred after 1492 in the Americas [1] [16] and in Europe [17]. The use of antibiotics in poultry [18], fish farming [19], and animal farming [20] contributed to and continues to contribute to antibiotic resistance and multiple antibiotic resistances, especially the spreading of MRSA. Bacteriocins and other cationic peptides/small proteins (such as lysozyme) became an antibiotic group for use for topical application and for use in the food industry [21]. The general problems in the mass production of these are the viscosity of raw material (as for lysozyme), or presence in the culture medium/Complex Medium of colloidal and fast-particle materials together with bacteria that are the producing source for bacteriocins [21] [22] [23] [24] [25]. Nearly the same problems are found in the production of antibiotics from all existing natural sources. All described protocols [21] [22] [23] [24] [25] and many others include numerous steps of precipitation, filtration, and even centrifugation prior to chromatographic purification. All described protocols recognize the loss of a significant part of activity and loss of target substance. All described protocols include the production of large volumes of liquid waste. These wastes contain antibacterial substances, remains of bacteria/molds, even small quantities of vital bacteria/molds, and significant quantities of nutrition broth, salts, and debris. Often the waste is not deactivated by sterilizing in autoclaves. All this waste, in some cases, is being canalized in nature/the environment, especially by pharmaceutical companies in developing countries. This is a significant contributor to the development of antibiotic resistance, multiple 
antibiotic resistance, and MRSA in wild creatures such as mammals, birds, fish, lizards, amphibians, and even in insects. From wild animals and vector insects that are carriers of microorganisms with resistance to antibiotics, the resistance to antibiotics is spreading to domesticated animals and to humans. By the vector insects, these are host organisms to microorganisms with strong single antibiotic resistance, multiple antibiotic resistance, and MRSA the resistance to antibiotics are also spreading to domesticated animals and to humans. The present paper describes a direct chromatographic procedure avoiding centrifugation, filtration, precipitation, and other time- and labor-consuming procedures. The advantages of the presented procedure are: 1) the high purity of the target substance, and 2) minimal loss of activity and target substance, if any, of antibacterial activity/antibacterial substance has been wasted. Generation of waste is minimal.

\section{Materials and Methods}

\subsection{Instrumentation}

For Colloidal High-Performance Liquid Chromatography (CHPLC) analysis, an HP 1100 instrument (Hewlett-Packard, Palo Alto, CA, USA) equipped with a diode array detector and ChemStation software were used. Detection was done at 245 and $254 \mathrm{~nm}$, and a simultaneous UV scan was obtained in the range 190 $400 \mathrm{~nm}$. The homemade analytical column was prepared by grafting glass fibers, similar to that described in [26]. Glass fibers with a diameter of $0.2 \mu \mathrm{m}$ were used in the experiment. The analytical column was $150 \mathrm{~mm}$ long and $4.6 \mathrm{~mm}$ (intern diameter) i.d. The homemade injector was a syringe type with a volume of $250 \mathrm{~mL}$. For chromatography, the following solutions were prepared: 1) glass-distilled purified water, 2) sterilized and centrifuged at $5000 \mathrm{rpm}$, Complex Medium was filtered through a $2 \mu \mathrm{m}$ filter, 3) eluate number 1 was $0.00001 \mathrm{M}$ $\mathrm{HCl} \mathrm{pH} \mathrm{6.04,} \mathrm{eluate} \mathrm{number} 2$ was $0.001 \mathrm{M} \mathrm{HCl} \mathrm{pH} \mathrm{3.26.} \mathrm{The} \mathrm{program} \mathrm{was} \mathrm{to}$ inject $250 \mathrm{~mL}$ of the culture medium, wash the column with three injector volumes of solution number 2, wash the column with $5 \mathrm{~mL}$ of solution number 1 (under injection and washing the detector was switched off), then start with $100 \%$ of eluate number 1 with a linear program for $45 \mathrm{~min}$ to $100 \%$ of eluate number 2, hold elution with eluate number 2 for $5 \mathrm{~min}$ and wash with glass-distilled purified water for $5 \mathrm{~min}$. After this regenerate column by washing with sterilized, centrifuged at $5000 \mathrm{rpm}$, and filtered through a $2 \mu \mathrm{m}$ filter Complex Medium for $5 \mathrm{~min}$. The column is then ready for a new cycle of chromatography. Column flow under the procedure was $9.9 \mathrm{~mL} / \mathrm{min}$.

\subsection{Biological Materials and Bacteriocin Assay}

Bacterial samples, cultivation, and testing of bactericide activities of bacteriocins are described in [21]. Bacitracin was obtained by cultivation of Bacillus licheniformis. Bacillus licheniformis and a Bacitracin Standard were purchased from Analytical Standards, (Analytical Standards, Analytical/Chromatography, Phar- 
macopeia \& Metrological Institutes Standards, USP Standards). Bacitracin's empirical formula with molecular weight $1422.69 \mathrm{amu}$ is $\mathrm{C}_{66} \mathrm{H}_{103} \mathrm{~N}_{17} \mathrm{O}_{16} \mathrm{~S}$.

Homogenized hen egg white diluted with distilled water (solution 1) 1 to 10 $\mathrm{v} / \mathrm{v}$ was prepared for the chromatographic isolation of lysozyme.

Every collected fraction was diluted with Complex Medium to $50 \mathrm{~mL}$ and its activity was tested against filtered culture medium. The final activity of a fraction was decided by the dilution at which the activity of the fraction was equal to the activity of the filtered culture medium. The bacteriocin assay details have been described in [21].

\section{Results}

The chromatogram of Complex Medium in which Lactobacillus sake NCDO 2714 (type strain has been cultivated) was used to demonstrate the ability of CHPLC. On trail A, the first part of the chromatogram has been presented and on trail B the second part has been presented (the chromatogram was too long to be presented as one piece, for presentation in the paper it was necessary to cut it into 2 parts) Figure 1. The most of antibacterial active substance was detected under the peak with $R_{t}=15.670$ min, the substances under peaks with $R_{t}=$ $10.945,31.686$, and $37.008 \mathrm{~min}$ were also antibacterial active, however with significantly lower activity.

The volume of the original fraction collected under the peak with $R_{t}=15.670$ min was less than $5 \mathrm{~mL}$; however, its antibacterial activity was equivalent to that of the culture medium of $200 \mathrm{~mL}$. By this, it is possible to estimate a minimal 40 -fold increase in activity. The purity of the substance under the peak with $\mathrm{R}_{\mathrm{t}}=$ 15.670 min has been analyzed by DAD with a simultaneous UV scan in the range $190-400 \mathrm{~nm}$ using ChemStation software. The purity of the fraction under the peak with $R_{t}=15.670$ min is more than $97 \%$. The spectral purity of the fraction under the peak exceeds the threshold limit at $99.7 \%$ (spectral purity analysis not shown).

The chromatography of homogenized hen egg white diluted with distilled water 1 to $10 \mathrm{v} / \mathrm{v}$ was subjected to chromatographic isolation of lysozyme (chromatogram not shown). One in ten $\mathrm{v} / \mathrm{v}$ solutions of lysozyme exceeded the viscosity of a solution that normally can be subjected to traditional HPLC; however, for the grafted glass fiber cationic column of CHPLC, this viscosity was not a problem.

Lysozyme, besides its medical application, is used in the study of the toxicity of pesticides and suppression of immunity by different pesticides [27]. Lysozyme is a glycoside hydrolase enzyme that normally catalyzes the hydrolysis of 1,4-beta linkages between $\mathrm{N}$-acetylmuramic acid and $N$-acetyl- $D$-glucosamine residues in peptidoglycan, which is the major component of gram-positive bacterial cell walls. However, it was shown that lysozyme can be active also against gram-negative bacterial cells by hydrolysis of links in LPS if detergents such as synthetic EDTA, or natural taurine or gal acids have been added [27]. Active 


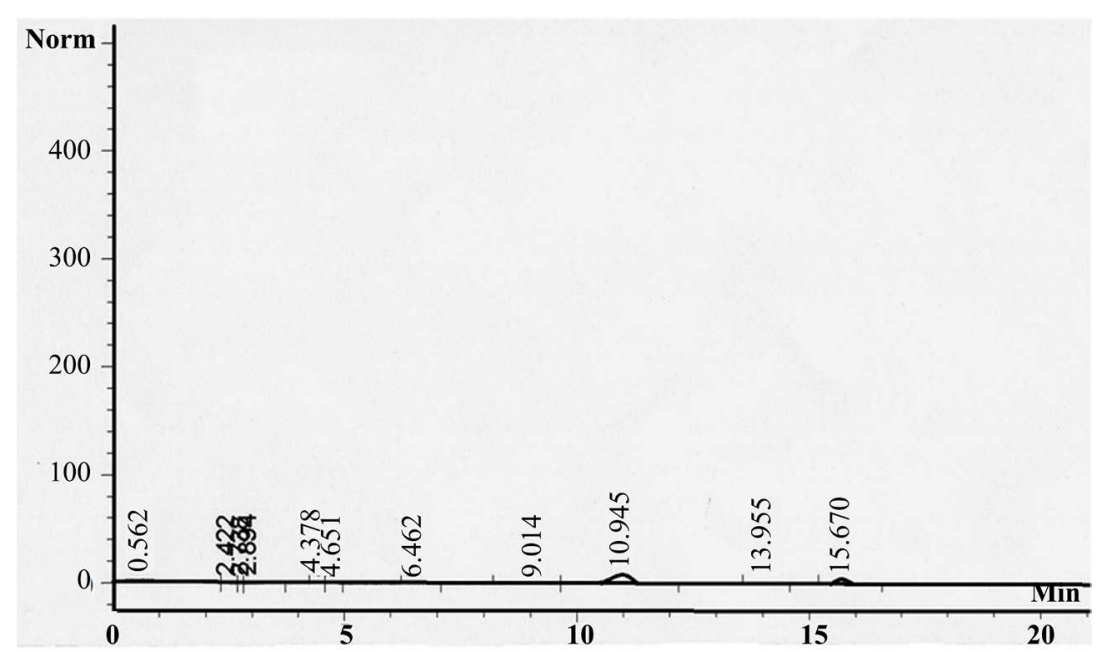

(A)

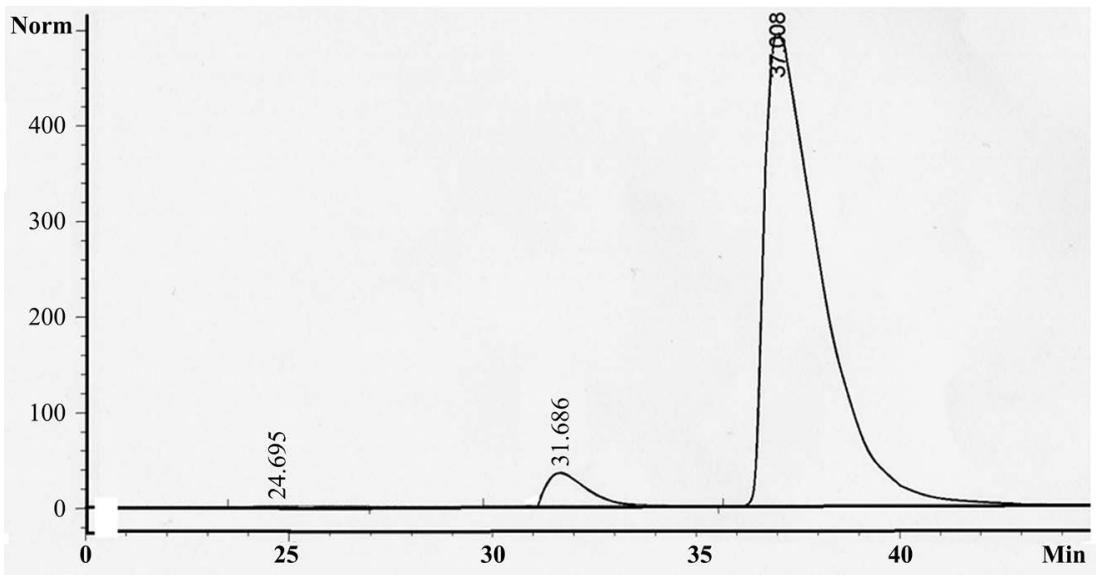

(B)

Figure 1. The chromatogram of complex medium in which lactobacillus sake NCDO 2714 (type strain) was cultivated. The A and B trails are the chromatograms recorded by $\mathrm{DAD}$ at $254 \mathrm{~nm}$.

lysozyme with purity more than $95.5 \%$ was isolated in the chromatographic experiment.

Finally, the bacitracin was chromatographically isolated from Complex Culture Medium inoculated with Bacillus licheniformis. The authenticity analysis of the bacitracin from the collected peak with $\mathrm{R}_{\mathrm{t}}=14.955$ min was judged by the retention time of bacitracin fraction/bacitracin standard, and the purity of the peak was more than $95 \%$ following the purity factor of the fraction analyzed by DAD with a simultaneous UV scan in the range $190-400 \mathrm{~nm}$, with references at 360 and $100 \mathrm{~nm}$, using ChemStation software for the peak at Rt $=14.955 \mathrm{~min}$; see Figure 2 and Figure 3.

A semipreparative glass grafted fiber cationic column of large dimension was prepared and is under evaluation. The possibility of chromatography by using CHPLC of other antibiotics and small molecular weight cationic/anionic substances is under evaluation. 
Purity results peak 2 at $14.955 \mathrm{~min}$.

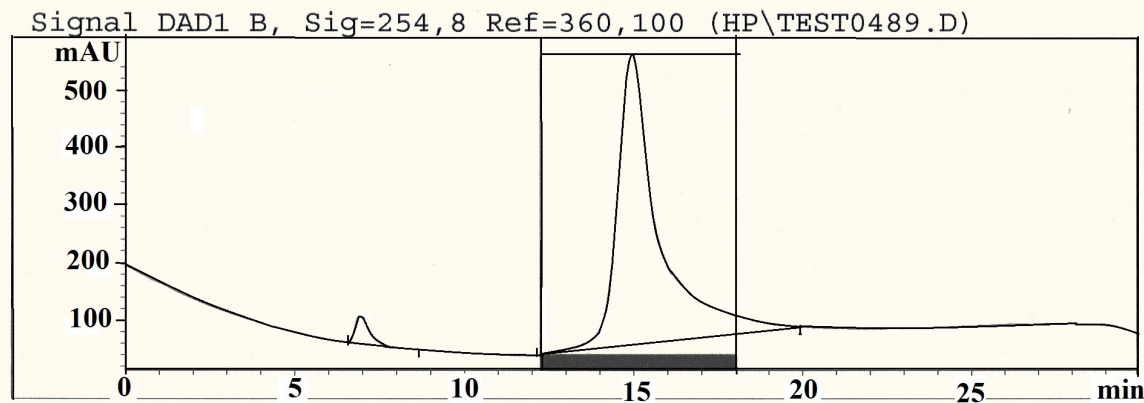

Figure 2. The peak at $\mathrm{R}_{\mathrm{t}}=14.955 \mathrm{~min}$.
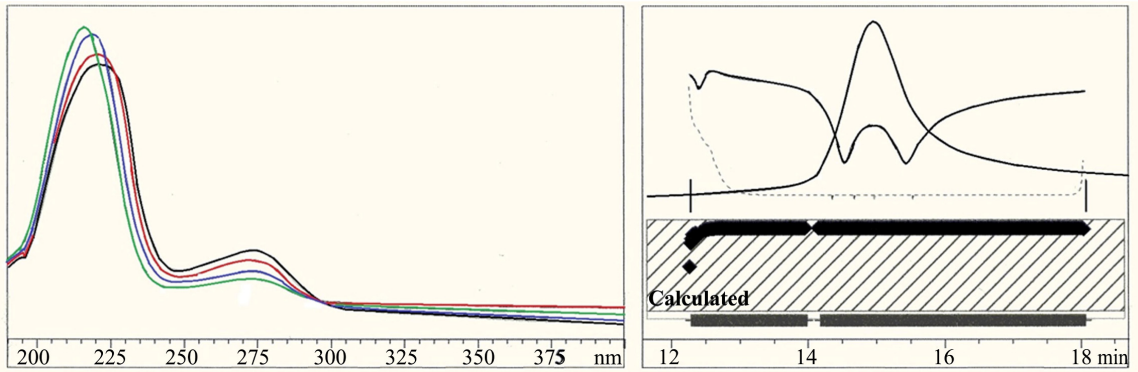

-> The purity factor exceeds the calculated threshold limit.

Purity factor : 745.963(421 of 421 spectra exceed the calculated

threshold limit

: 997.215 (Calculated with 421 of 421 spectra)

: Manual selected (12.249/18.049)

Spectra $\quad: 5$ (Selection automatic, 5$)$

Noise Threshol : 0.115 (12 spectra, St Dev $0.0589+3 * 0.0186$

Warning : Spectral absorbances $1000 \mathrm{mAu}$ (see help for more information)

Figure 3. The purity factor for the fraction with peak $R_{t}=14.955 \mathrm{~min}$. The structural formula of bacitracin is shown in Figure 4.

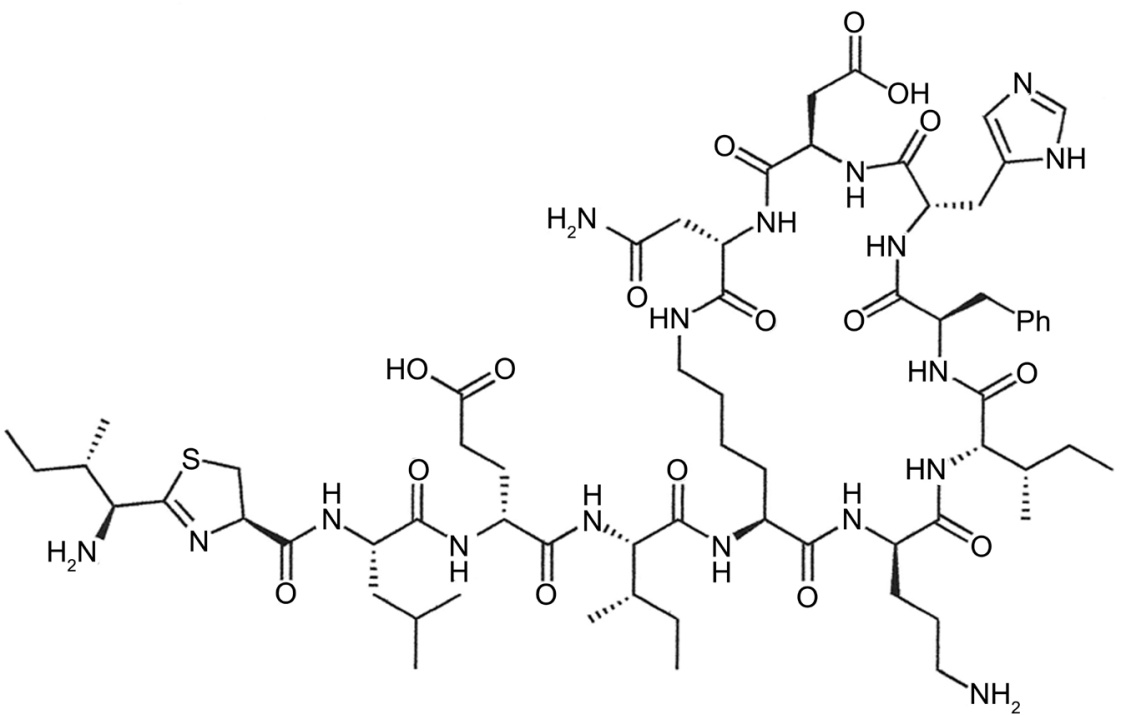

Figure 4. The structural formula of bacitracin. 


\section{Discussion}

The main technological achievement of CHPLC is direct possibility to use colloidal liquids by HPLC columns without of clotting danger. It was possible because of special arrangement of fibers in the column, absence of sinter in the head of column and the sinter with $0.5 \mathrm{~mm}$ at the bottom of column.

\section{Conflicts of Interest}

The author declares no conflicts of interest regarding the publication of this paper.

\section{References}

[1] Brondz, I. (2016) Super Antibiotics, Part I. Hyperforin. Voice of the Publisher, 2, 19-27. https://doi.org/10.4236/vp.2016.24004

[2] Daw, M.A. and Falkiner, F.R. (1996) Bacteriocins: Nature, Function and Structure. Micron, 27, 467-479. https://doi.org/10.1016/S0968-4328(96)00028-5

[3] Gratia, J.P. (2000) André Gratia: A Forerunner in Microbial and Viral Genetics. Genetics, 156, 471-476.

[4] Brondz, I. (1979) Antibiotikumet "Hyperforin" og andre innholdsstoffer i drogen Hypricum perforatum L. Thesis (Cand. Pharm.) University of Oslo, Oslo. (In Norwegian)

[5] Brondz, I., Greibrokk, T., Groth, P.A. and Aasen, A.J. (1982) The Relative Stereochemistry of Hyperforin-An Antibiotic from Hypericum perforatum L. Tetrahedron Letters, 23, 1299-1300.

[6] Brondz, I., Greibrokk, T., Groth, P. and Aasen, A.J. (1983) The Absolute Configuration of Hyperforin, an Antibiotic from Hypericum perforatum L., Based on the Crystal Structure Determination of Its $p$-Bromobenzoate Ester. Acta Chemica Scandinavica, 37A, 263-265. https://doi.org/10.3891/acta.chem.scand.37a-0263

[7] Brondz, I. (1986) Lecture Entitled "The Influence of Hyperforin on Phagocytosis of E. coli by Human Polymorphonuclear Neutrophils in Vitro. Norlændska Infektionssjkdo-mar Symposium, Vårmøteti Sundsvall, 14-15 May 1986. https://www.researchgate.net/publication/233795016_The_influence_of_hyperforin _on_phagocytosis_of_Ecoli_by_human_polymorphonuclear_neutrophils_in_vitro

[8] Brondz, I. (1987) Influence of Hyperforin upon Phagocytic Functions in Human Poly Morphonuclear Leucocytes. 4th International Conference on Chemistry and Biotechnology of Biological Active Natural Products, Budapest, Hungary, 1987, abstr. B-15, 119.

[9] Brondz, I. (2012) Enhancement of the Immunity in AIDS and Other Immuno Compromised Patients by Hyperfor in an Antibiotic from Hypericum perforatum L. In: Oficialus Lietuvos Bendrosios Praktikos Gydytoju Kolegijos Leidinys, No. 7, $2^{\text {nd }}$ ARIP European Conference on Antimicrobial Resistance \& Infection Prevention, Vilnius, Lithuania, 4-5 October 2012, P12, 60.

[10] Brondz, I. and Brondz, A. (2012) Recent Enhancement of the Immunity in AIDS and Other Immunocompromised Patients by Hyperfor in an Antibiotic from Hypericum perforatum L. (in Vitro Model) Part I. Journal of Biophysical Chemistry, 3, 304-310. https://doi.org/10.4236/jbpc.2012.34037

[11] Brondz, I. (2016) Super Antibiotics, Part II. Hyperforin, Mass Spectroscopy (MS) and Gas Chromatography-Mass Spectrometry (GC-MS), Evidence of Permeability of the Blood-Testis Barrier (BTB) and the Blood-Brain Barrier (BBB) to Hyperforin. 
International Journal of Analytical Mass Spectrometry and Chromatography, 4, 66-73. https://doi.org/10.4236/ijamsc.2016.44007

[12] Brondz, I. (2017) Super Antibiotics: Part III. Hyperforin, Revision of the Relative and Absolute Stereochemistry Presented by Bystrov et al. Voice of the Publisher, 3 , 15-24. https://doi.org/10.4236/vp.2017.32002

[13] Brondz, I. (2017) Super Antibiotics, Part IV. Hyperforin, Relative and Absolute Stereo-Chemistry Elucidated by Gas-Chromatography Mass-Spectrometry with Supersonic Molecular Beams. International Journal of Analytical Mass Spectrometry and Chromatography, 5, 70-85. https://doi.org/10.4236/ijamsc.2017.53005

[14] Brondz, I. (2017) Super Antibiotics: Part V. Doxycycline. Voice of the Publisher, 3, 53-58. https://doi.org/10.4236/vp.2017.34006

[15] Monge-Maillo, B. and Lopez-Velez, R. (2012) Migration and Malaria in Europe. Mediterranean Journal of Hematology and Infectious Diseases, 4, e2012014. https://doi.org/10.4084/mjhid.2012.014

[16] Denevan, W.M. (1992) The Native Population of the Americas in 1492. The University of Wisconsin Press, Madison. https://uwpress.wisc.edu/books/0289.htm

[17] Crosby Jr., A.W. (1969) The Early History of Syphilis: A Reappraisal. American Anthropologist, 71, 218-227. https://doi.org/10.1525/aa.1969.71.2.02a00020

[18] Ansari, F.A. and Khatoon, H. (1994) Multiple Antibiotic Resistance among Gram Negative Bacteria Isolated from Poultry. Indian Journal of Experimental Biology, 32, 211-212.

[19] Kathleen, M.M., Samuel, L., Felecia, C., Reagan, E.L., Kasing, A., Lesley, M. and Toh, S.C. (2016) Antibiotic Resistance of Diverse Bacteria from Aquaculture in Borneo. International Journal of Microbiology, 2016, Article ID: 2164761.

[20] Economou, V. and Gousia, P. (2015) Agriculture and Food Animals as a Source of Antimicrobial-Resistant Bacteria. Infection and Drug Resistance, 1, 49-61. https://doi.org/10.2147/IDR.S55778

[21] Uteng, M., Hauge, H.H., Brondz, I., Nissen-Meyer, J. and Fimland, G. (2002) Rapid Two-Step Procedure for Large-Scale Purification of Pediocin-Like Bacteriocins and Other Cationic Antimicrobial Peptides from Complex Medium. Applied and Environmental Microbiology, 68, 952-956.

https://www.ncbi.nlm.nih.gov/pubmed/11823243

https://doi.org/10.1128/AEM.68.2.952-956.2002

[22] Valery Borzenkov, V., Surovtsev, V. and Dyatlov, I. (2014) Obtaining Bacteriocins by Chro-Matographic Methods. Advances in Bioscience and Biotechnology, 5, 446-445. https://doi.org/10.4236/abb.2014.55054

[23] Holo, H., Nilssen, Ø. and Nes, I.F. (1991) Lactococcin A, a New Bacteriocin from Lactococ-cus lactis subsp. cremoris. Isolation and Characterization of the Protein and Its Gene. Journal of Bacteriology, 173, 3879-3887.

https://www.ncbi.nlm.nih.gov/pmc/articles/PMC208020/

[24] Rodriguez, J.M., Martinez, M.I. and Kok, J. (2002) Pediocin PA-1, a Wide-Spectrum Bacteriocin from Lactic Acid Bacteria. Critical Reviews in Food Science and Nutrition, 42, 91-121. https://www.ncbi.nlm.nih.gov/pubmed/11934133 https://doi.org/10.1080/10408690290825475

[25] Pingitore, E.V., Salvucci, E., Sesma, F. and Nader-Macías, M.E. (2007) Different Strategies for Purification of Antimicrobial Peptides from Lactic Acid Bacteria (LAB). In: Méndez-Vilas, A., Ed., Communicating Current Research and Educational Topics and Trends in Applied Microbiology, 557-568. 
http://file:///C:/Users/Llia/Desktop/Bacteriocin/pages557-568.pdf

[26] Etcheverry, M., Damiani, D.E., Ferreira, M.L., Barbosa, S.E. and Capiati, N.J. (2008) Chemical Grafting of Metallocene-Catalyzed Functional Polypropylene Copolymer on Glass Substrates through Surface Modification. Journal of Applied Polymer Science, 109, 2815-2822. https://doi.org/10.1002/app.28177 https://onlinelibrary.wiley.com/doi/abs/10.1002/app.28177

[27] Brondz, I. and Brondz, A. (2011) Suppression of Immunity by Some Pesticides, Xenobiotics, and Industrial Chemicals. In Vitro Model. Journal of Biophysical Chemistry, 2, 226-232. https://doi.org/10.4236/jbpc.2011.23028 